\title{
Geothermal Repurposing of Depleted Oil and Gas Wells in Italy ${ }^{\dagger}$
}

\author{
Elena Soldo ${ }^{1, *}$, Claudio Alimonti ${ }^{1}$ and Davide Scrocca ${ }^{2}$ \\ 1 The Department Chemical Engineering Materials Environment (DICMA), Università degli Studi di Roma \\ La Sapienza, 00185 Roma, Italy; claudio.alimonti@uniroma1.it \\ 2 Consiglio Nazionale delle Ricerche, Istituto di Geologia Ambientale e Geoingegneria, 00185 Roma, Italy; \\ davide.scrocca@igag.cnr.it \\ * Correspondence: elena.soldo@unroma1.it \\ † Presented at the First World Energies Forum, 14 September-05 October 2020; Available online: \\ https://wef.sciforum.net/.
}

Published: 11 September 2020

\begin{abstract}
The decarbonisation of the energy sector is probably one of the main worldwide challenges of the future. Global changes urge a radical transformation and improvement of the energy-producing systems to meet the decarbonisation targets and a reduction of greenhouse gas emissions. The hydrocarbon industry also contributes to this transition path. In a mature stage of oil and gas fields, the production of hydrocarbons is associated with formation waters. The volume of produced water increases with the maturity of the assets and the geothermal repurposing of depleted oil and gas wells could be an alternative to the mining closure. In the described transition scenario, the geothermal energy seems very promising because of its wide range of applications depending on the temperature of extracted fluids. This flexibility enables us to propose projects inspired by a circular economic vision considering the integration in the territory and social acceptance issues. In Italy, since 1985, 7246 wells have been drilled for hydrocarbon, of which 898 are located onshore with a productive or potentially productive operational status. This paper presents a preliminary investigation of oil and gas fields located onshore in Italian territory based on the available information on temperature distribution at different depths. Then, taking into account the local energy demand, existing infrastructure, and land use of the territory, a conversion strategy for the producing wells is proposed for three case studies.
\end{abstract}

Keywords: geothermal energy; hydrocarbons; decarbonisation; oil and gas

\section{Introduction}

One of the main challenges of the future is the decarbonisation of the energy sector. Global changes urge a radical transformation and improvement of the energy-producing systems to meet the decarbonisation targets of the European economy and reduce greenhouse gas emissions. The main targets for 2030 are a reduction of $40 \%$ of greenhouse gases, an increase in renewable energy of $27 \%$, and an increase in the energy efficiency of $27 \%$. For 2050 the targets in Europe are higher, with a reduction in emissions of around $90 \%$, an increase in energy from renewables to $75 \%$, and an increase in energy efficiency to $41 \%$.

Current heating and cooling plants are a major contributor to the EU's greenhouse gas emissions. Forty-seven per cent of the final energy consumption in the EU is due to heating and cooling (domestic and industrial) and $81 \%$ of the heating is produced through the combustion of fossil fuels while cooling predominantly is produced from electricity-driven processes (today largely generated by burning coal and gas). Geothermal energy can contribute to the diffusion of low-carbon technologies for the generation of electricity, heating, and cooling. 
Finding alternative energy sources to hydrocarbons, optimizing energy production, integrating different energy sources, and reducing waste heat and environmental impacts are some of the current objectives for a successful energy transition in modern industrial societies. For these purposes, it should be considered that the oil and gas production in its mature stage is often associated with a large volume of formation waters, which must be treated continuously and cannot be released into the environment. Increasing the maturity of hydrocarbon fields increases water production as well. So, when the hydrocarbons wells are going to be depleted, they can be converted into geothermal wells. Some studies evaluated the potential heat recovery from oil and gas fields worldwide. Ref [1] estimated that the use of co-produced fluids in oilfields along the Gulf Coast could produce over 1 GW of electric power. Ref [2] stated that the use of oilfields of Los Angeles may generate 7.43 MW of net power and [3] reported that 4,241,018 J of recoverable geothermal energy is stored in the Chinese oilfields. Moreover, [4] reported a summary of the worldwide oilfield geothermal direct use projects: Austria has used the water of abandoned wells since 1970 to feed spa resorts; in Albania, the water is used in greenhouse heating; heat trace oil gathering is carried out in China and Hungary; and in China, the space heating projects are numerous. The selection of the final use (production of thermal power or electricity) and the potential of geothermal production depend on the temperature, pressure, and flow rate of water, which are functions of the local geothermal gradient, well-depth, and poro-perm properties of the reservoir rocks.

The first example of co-production or geothermal application of gas wells is the pilot plant in Pleasant Bayou field where, in 1980, a 1 MW hybrid cycle power plant was built to demonstrate the possibility of using existing wells to extract both gas and hot water and to produce electricity [5]. Since then, several studies on geothermal energy production from abandoned oil and gas fields have been conducted [6-25].

In this context, a key point for the geothermal sector is the need to reduce uncertainties on profitability and to design sustainable solutions for large-scale development out of the conventional assets. The possibility of a crossover from oil and gas to geothermal energy production represents a chance for Italy to increase the share of renewable energy production and to reduce the waste heat. The target of this work is to produce a vision of the potential benefits resulting from the reuse of depleted oil and gas wells in Italy. Starting from the available information on fields and wells provided by the Ministry of Economic Development and on-field temperatures from the Italian National Geothermal Database [26], a selection of the most promising areas has been conducted. Among these fields, three case studies representative of different petroleum systems and geological settings have been selected for a preliminary survey of the possible geothermal reuse. Taking into account the local energy demand, existing infrastructure, and land use of the territory, a conversion strategy for the active wells has been evaluated.

\section{Italian Petroleum Systems}

An overview of the geological settings of the main petroleum systems in Italy, and the associated active hydrocarbon fields, has been carried out to properly frame the detailed analysis of our case studies.

Hydrocarbon occurrences in Italy (fields, discoveries, and shows) are associated with both carbonate and siliciclastic reservoir rocks ranging in age from the Triassic to the Paleogene and from the Oligocene to the Pleistocene, respectively, distributed in thrust belt, foredeep basin, and foreland geological settings (Figure 1) [27-35].

Based on the main source rocks ([34,36-38] and references therein), at least five major petroleum systems [39] can be recognised in Italy. The approximate geographic extent of these petroleum systems and the stratigraphic distribution of the known source rocks and hydrocarbon occurrences are shown in Figure 1 (after [34]). Three of these petroleum systems, mainly oil-prone, are associated with Meso-Cenozoic passive margin sedimentary covers that are made up of shallow water and pelagic carbonates, evaporites, and clastics sedimented following the Mesozoic extensional tectonic stages. The last two petroleum systems, essentially gas-prone, are instead related to terrigenous Oligo-Miocene and Plio-Pleistocene foredeep units deposited during the development of the Alpine 
and Apennines orogens. The main characteristics of these five petroleum systems [27-35] are briefly summarized in Table 1.
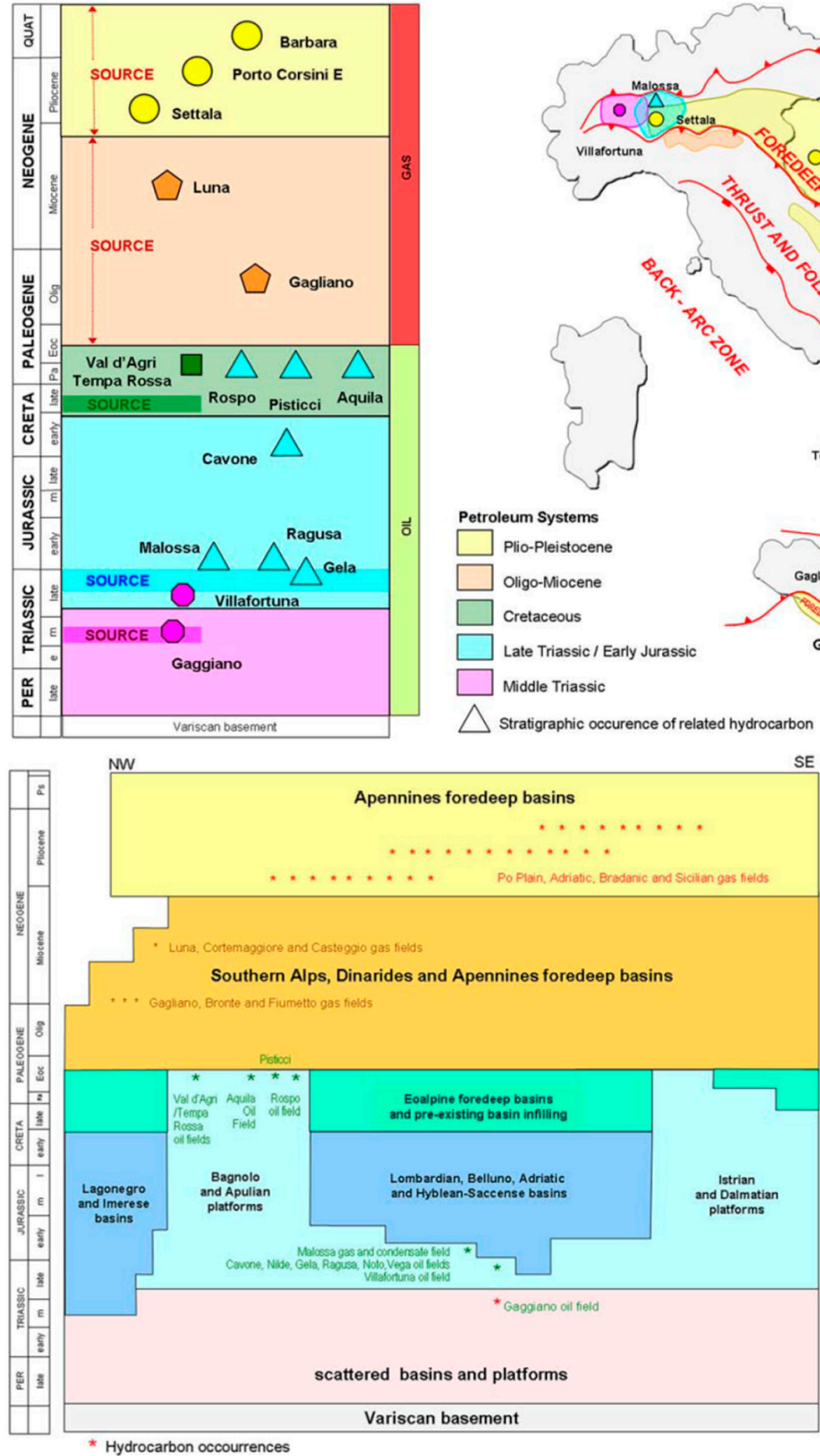

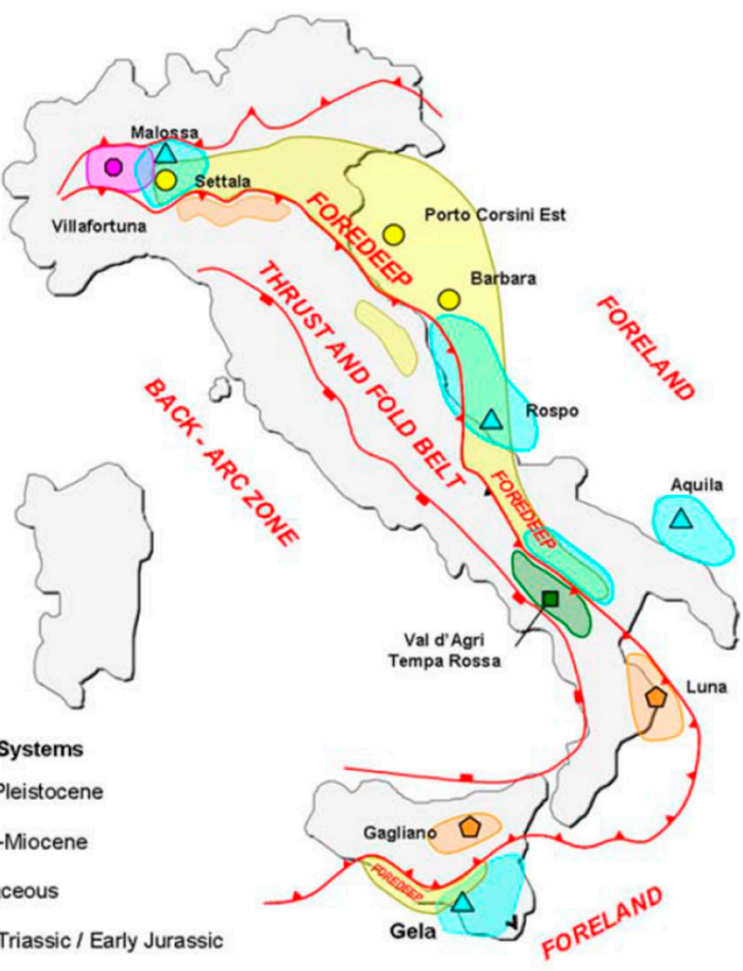

Late Triassic / Early Jurassic

Middle Triassic

Statgraphic occur

Stratigraphic occurence of related hydrocarbon

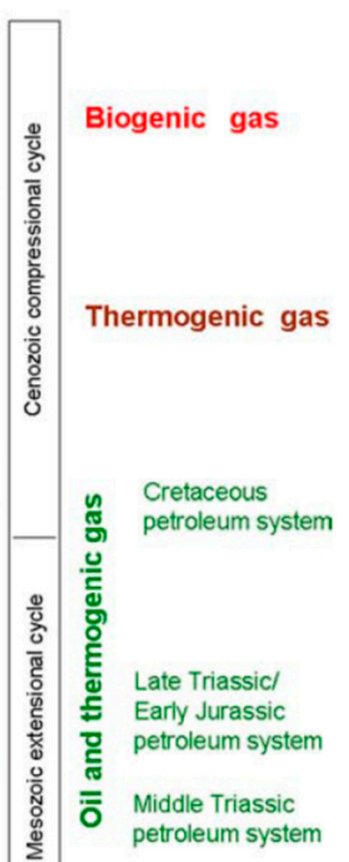

Figure 1. The geographic location of the five petroleum systems recognised in Italy (above, right), stratigraphic distribution of the related source rocks and hydrocarbon occurrences (above, left), and relationships between hydrocarbon occurrences and the tectono-stratigraphic setting (below; after [34]). 
Table 1. Italian petroleum system and typical associated fields.

\begin{tabular}{|c|c|c|}
\hline $\begin{array}{c}\text { Petroleum } \\
\text { System }\end{array}$ & Reservoir Source Rock & Representative Fields \\
\hline Middle Triassic & $\begin{array}{l}\text { Fractured and dolomitized shelf carbonates, } \\
\text { hosted in trust-related folds and sealed by marly } \\
\text { and volcanoclastic units, are charged by the } \\
\text { Besano Shales (Anisian/Ladinian) and Meride } \\
\text { Limestone (Ladinian) source rocks. }\end{array}$ & $\begin{array}{l}\text { Villafortuna-Trecate oil } \\
\text { field, discovered in } 1984 \\
\text { with a cumulative } \\
\text { production at the end of } \\
2000 \text { of } 188 \text { Mbo of } 43^{\circ} \text { API } \\
\text { oil and more than } 2000 \\
\text { MSTm3 of gas. } \\
\end{array}$ \\
\hline $\begin{array}{l}\text { Late Triassic- } \\
\text { Early Jurassic }\end{array}$ & $\begin{array}{l}\text { Oil accumulations in a variety of stratigraphic } \\
\text { intervals of the Mesozoic-Early Cenozoic } \\
\text { sedimentary cover overlying Late Triassic-Early } \\
\text { Jurassic source rocks in traps generally } \\
\text { represented by reactivated structures occurring } \\
\text { along the foreland margin. }\end{array}$ & $\begin{array}{l}\text { Gela oil field in Sicily } \\
\text { discovered in } 1956 \text { with } \\
\text { reserves of 130-150 Mbo. }\end{array}$ \\
\hline Cretaceous & $\begin{array}{l}\text { The reservoir is made up by Cretaceous-Middle } \\
\text { Miocene fractured shallow-water limestone and } \\
\text { dolostones sealed by shaly units in traps } \\
\text { represented by thrust-related folds. It is charged } \\
\text { by an Albian-Cenomanian organic-rich } \\
\text { carbonate source rock deposited in isolated } \\
\text { basins developed during the Cretaceous anoxic } \\
\text { events within the long-lasting Apulian } \\
\text { carbonate platform. }\end{array}$ & $\begin{array}{c}\text { Val d'Agri oil field, } \\
\text { discovered in } 1988 \text { with } \\
\text { estimated reserves of about } \\
480 \text { Mbo of } 26^{\circ}-42^{\circ} \text { API oil. }\end{array}$ \\
\hline $\begin{array}{l}\text { Thermogenic } \\
\text { gas in Oligo- } \\
\text { Miocene } \\
\text { foredeep }\end{array}$ & $\begin{array}{l}\text { This system is associated with an early } \\
\text { thermogenic generation from the gas-prone } \\
\text { organic matter contained in the shaly levels that } \\
\text { charged the turbidite reservoirs. Hydrocarbon } \\
\text { accumulations hosted in structural traps with } \\
\text { some light oil and condensate. }\end{array}$ & $\begin{array}{l}\text { Typical examples are the } \\
\text { Gagliano and Luna gas } \\
\text { fields. }\end{array}$ \\
\hline $\begin{array}{l}\text { Biogenic gas in } \\
\text { Plio-Pleistocene } \\
\text { foredeep }\end{array}$ & $\begin{array}{l}\text { The sand-rich turbidite reservoir is charged with } \\
\text { biogenic gas by the interbedded clay levels, } \\
\text { characterised by an organic matter of terrestrial } \\
\text { origin, which also provides the seal. Traps are } \\
\text { usually structural although several stratigraphic } \\
\text { traps have been also recognised. }\end{array}$ & $\begin{array}{l}\text { Porto Corsini East and } \\
\text { Barbara gas fields. }\end{array}$ \\
\hline
\end{tabular}

\section{Materials and Methods}

The National Mining Office of the Italian Ministry for Economic Development (MISE) provides information and data regarding productive oil and gas wells, and hydrocarbon and gas storage licences in Italy [40]. Data are also provided by the website of the project "Visibility of petroleum exploration data in Italy" [41] promoted by the MISE-DGRME (Direzione Generale Risorse Minerarie ed Energetiche), the Italian Geological Society, and the Assomineraria association. Additional information on the location and characteristics of the Italian hydrocarbon fields have been retrieved from literature (e.g., [27,28,30,32-34,42-44]).

The MISE reported, at the end of November 2019, 93 research permits and 193 production concessions, while the active hydrocarbon wells (as of February 2019) numbered 2166 in total, of which 898 were located onshore with a productive or potentially productive operational status (Figure 2). 

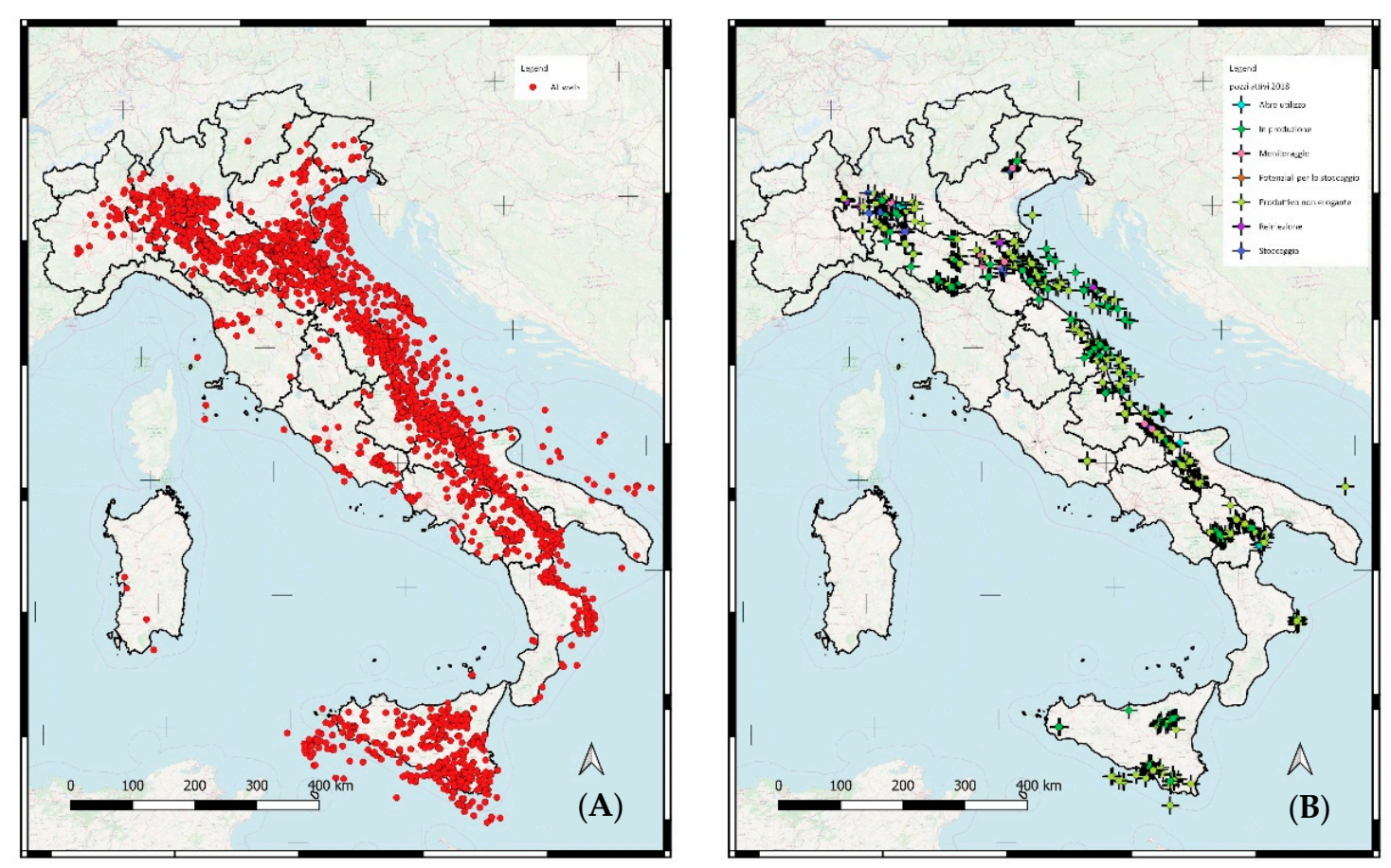

Figure 2. Oil and gas wells in Italy. (A) The complete collection, (B) Only active wells in 2019.

For this contribution, we selected only the onshore fields that had productive (or potentially productive) wells. We then cross-checked the position of these fields with the available information on the temperature at depth. To get the results, and taking into consideration that this was a firstpass national screening, we adopted a simple approach using the temperature maps at depths -1000 , -2000 , and $-3000 \mathrm{~m}$ below ground level published by [45], also available in the Italian National Geothermal Database [26].

The selection criterion to identify the promising fields was based on the lower temperature for possible applications. The chosen temperature was $70{ }^{\circ} \mathrm{C}$, interesting for direct uses, and the temperature maps used in the selection were limited to -2000 and $-3000 \mathrm{~m}$. The selected fields are located in areas where the temperature estimated at $-3000 \mathrm{~m}$ and $-2000 \mathrm{~m}$ was higher than $70{ }^{\circ} \mathrm{C}$ according to the total depth of the existing wells. Moreover, in the Bradano foredeep, the selection also includes fields that overlap areas with a temperature higher than $60{ }^{\circ} \mathrm{C}$ at $-2000 \mathrm{~m}$. With the approach described above, 42 fields were identified. Among those fields, 23 fields were deeper than $3000 \mathrm{~m}$ with a temperature higher than $70^{\circ} \mathrm{C}$ while, at a depth between 2000 and $3000 \mathrm{~m}, 9$ fields had a temperature higher than $70{ }^{\circ} \mathrm{C}$ and 10 fields had a temperature higher than $60^{\circ} \mathrm{C}$ (Figure 3). 


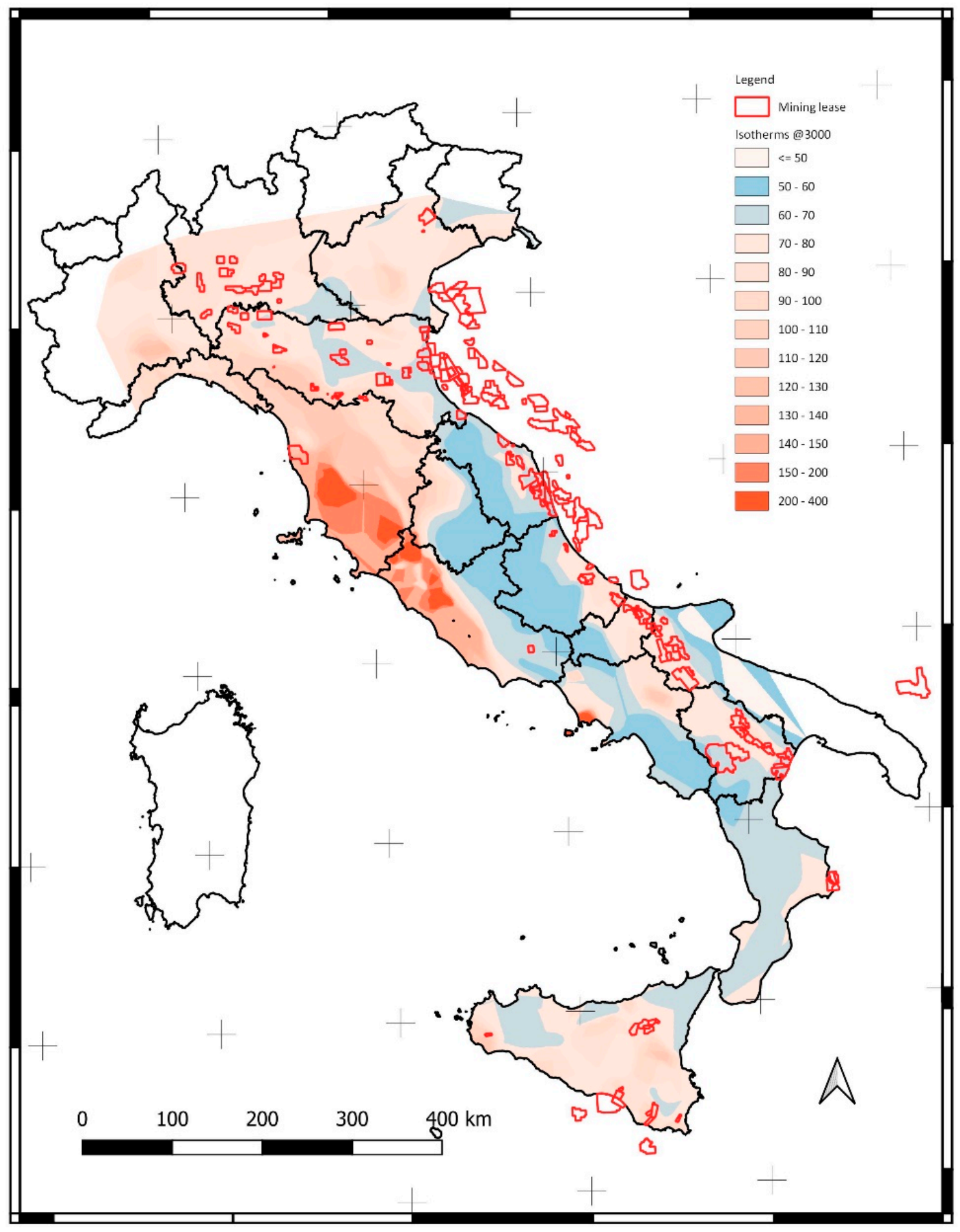

Figure 3. Production concessions with productive or potentially productive wells overlaid on the map with the estimated temperature at $-3000 \mathrm{~m}$ below ground level (after [45]).

\section{Case Studies}

A few representative case studies have been selected for which the available data allow a more detailed analysis. These case studies are the Villafortuna-Trecate and Gaggiano fields in Northern Italy (Middle Triassic petroleum system in the thrust belt in Northern Italy) and the Irminio field (Late Triassic-Early Jurassic petroleum system in the Hyblean foreland domain in Sicily). 


\subsection{Villafortuna-Trecate}

Villafortuna-Trecate is a field located in the Piemonte region, between the municipalities of Trecate, Romentino, and Galliate (Figure 4). The larger part of the wells is near Galliate and Romentino. A cascade plant system composed of an Organic Rankine Cycle (ORC) power plant, a district heating plant, and an aquaculture plant is proposed. One system will serve the municipality of Galliate and a second one the Romentino. For the municipalities of Galliate and Romentino, there are, respectively, six wells and three wells available. The produced water, after use, will be sent to existing reinjection wells.

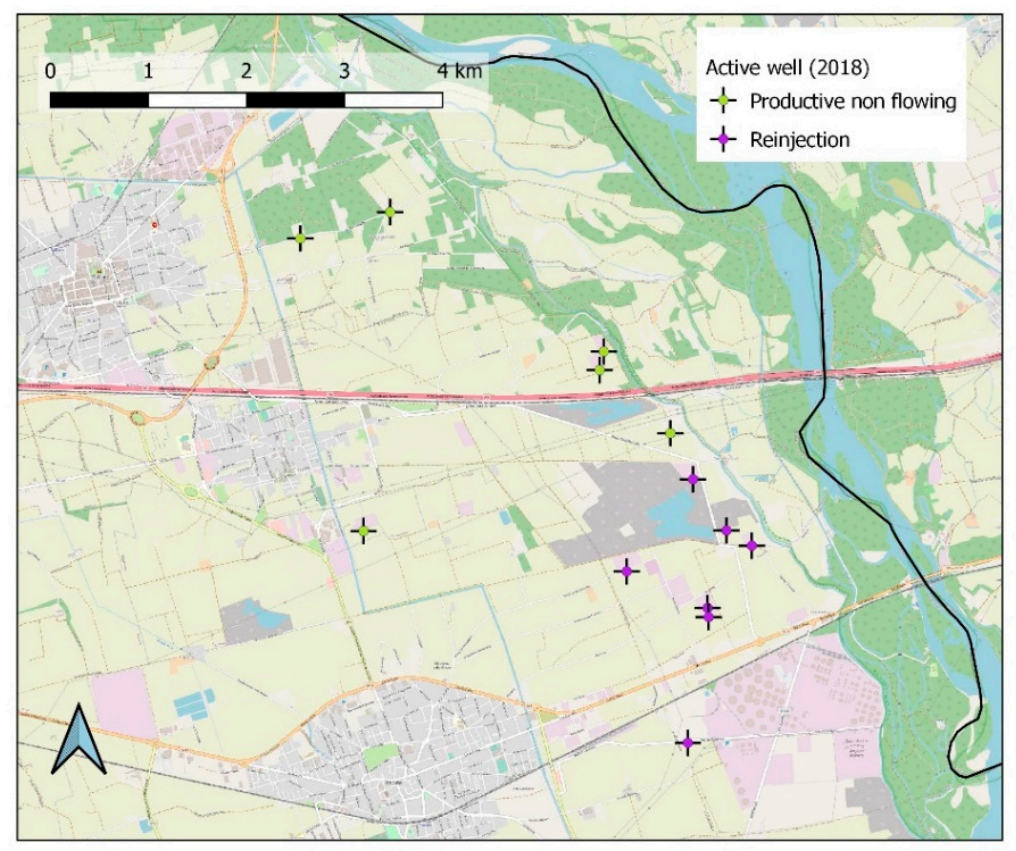

Figure 4. The Villafortuna-Trecate field. Wells and Municipalities.

From literature data and based on a previous analysis of productive well potential [14], the single well can produce a flow rate of $100 \mathrm{~kg} / \mathrm{s}$ of hot water having a wellhead brine temperature of $130^{\circ} \mathrm{C}$.

The geothermal fluid is supplied first to the ORC plant. A thermodynamic analysis of the binary plant, the working fluid selection (isobutane), the sizing of the condenser, and the cooling tower is included. To evaluate the number of supplied consumers, a precautionary consumption per capita of $1400 \mathrm{kWh}$ per year was assumed.

From the preheater of the ORC plant, the geothermal fluid at a temperature of $84^{\circ} \mathrm{C}$ is fed to the district heating $(\mathrm{DH})$ plant. Assuming a heating request of $2 \mathrm{~kW}$ per person, the number of inhabitants served was evaluated. The geothermal brine exits from the heat exchanger of the DH plant at the temperature of $50{ }^{\circ} \mathrm{C}$, suitable for aquaculture applications.

For the aquaculture plant, the selected species is shrimp, which need a constant water temperature of $35^{\circ} \mathrm{C}$. Indoor ponds constitute the plant. The annual heat requirement supplied by the geothermal energy includes the heat loss from convection, radiation, and evaporation. The evaluation assumes the following mean values for air properties: air temperature of $20^{\circ} \mathrm{C}$, relative humidity of $30 \%$, and saturation pressure of 0.007 bar.

Tables 2 and 3 illustrate the basic data of plants and economic pre-feasibility.

The results indicate that the proposed power plants, whose size guarantees a surplus of energy to be sold, can supply the yearly electrical demand of Galliate and Romentino municipalities. The cost of the power plants was obtained considering a mean value of $2000 € / \mathrm{kW}$. An energy price of $0.06 € / \mathrm{kWh}$ and a working time of $7500 \mathrm{~h}$ were used to evaluate the annual revenues. The estimated annual revenues ensure the recovery of the investment in 4.5 years for the power plant of Galliate and in 5 years for the power plant of Romentino. 
Table 2. Galliate cascade plant system.

\begin{tabular}{cccc}
\hline & Power Plant & DH Plant & Aquaculture Plant \\
\hline Inhabitants/Pond area & \multicolumn{2}{c}{15,700} & $4500 \mathrm{~m}^{2}$ \\
Power (MW) & 6 & 22.5 & - \\
Energy produced (MWh) & 45,000 & & - \\
Supplied consumers & 32,143 & 11,268 & - \\
Plant cost $(\mathrm{M} €$ ) & 12 & 40.5 & 0.697 \\
Revenues per year (M€) & 1.7 & 5.25 & 0.14 \\
Payback time (year) & 4.5 & 7.7 & 4.9 \\
\hline
\end{tabular}

Table 3. Romentino power plant.

\begin{tabular}{cccc}
\hline & Power Plant & DH Plant & Aquaculture Plant \\
\hline Inhabitants/Pond area & \multicolumn{3}{c}{5635} \\
Power (MW) & 3 & 11.2 & $2800 \mathrm{~m}^{2}$ \\
Energy produced (MWh) & 22,500 & & - \\
Supplied consumers & 16,071 & 5635 & - \\
Plant cost (M€) & 6.6 & 21 & - \\
Revenues per year (M€) & 1.35 & 2.7 & 0.456 \\
Payback time (year) & 5 & 7.75 & 0.088 \\
\hline
\end{tabular}

The DH plants may guarantee the cover of the thermal need of $71 \%$ of inhabitants of Galliate and $100 \%$ of inhabitants of Romentino. To estimate the DH plant cost, a value of $1800 € / \mathrm{kW}$ was used. Considering 3110 working hours per year and a price of thermal energy equal to $0.075 € / \mathrm{kWh}$, the investment cost would be recovered in about eight years for both of the municipalities.

For the economic evaluation of the aquaculture plants, two values were used for the installation cost, $155 € / \mathrm{m}^{2}$ for the plant of Galliate and $163 € / \mathrm{m}^{2}$ for the plant of Romentino. Considering a price of $7 € / \mathrm{kg}$ for the shrimp and a shrimp production of $4.5 \mathrm{~kg} / \mathrm{m}^{2}$, the payback period would be about five years for both of the plants.

\subsection{Gaggiano}

The oil field of Gaggiano is located in the southwestern portion of the Province of Milan and belongs to Middle Triassic petroleum system in the thrust belt in Northern Italy. The selected wells are located near the municipalities of Tainate and Noviglio (Figure 5). The production performance, based on the analogy with the Trecate field, is more conservative with a flow rate of $50 \mathrm{~m}^{3} / \mathrm{h}$, and the wellhead temperature of the water is estimated to be $125{ }^{\circ} \mathrm{C}$. Considering the availability of two production wells and one injection well, and the agricultural vocation of the territory, the proposed cascade scheme is composed of a DH plant, a greenhouse, and an aquaculture plant.

From the two wells, it is possible to obtain a thermal power of $6 \mathrm{MW} ; 2 \mathrm{MW}$ will be used to feed the greenhouses and $4 \mathrm{MW}$ to feed the DH plant. For both of the plants, the outlet temperature of the feeding water is $70{ }^{\circ} \mathrm{C}$; this fluid will be mixed with water at $20^{\circ} \mathrm{C}$ to supply the thermal request of an aquaculture system.

Assuming a heating request of $2 \mathrm{~kW}$ per person, the plant may guarantee the cover of the thermal need of $40 \%$ of inhabitants of Gaggiano. Using the same hypotheses of the Trecate case study for the plant cost, energy price, and the total number of working hours, the recovery time of investment cost is 7.4 years. 


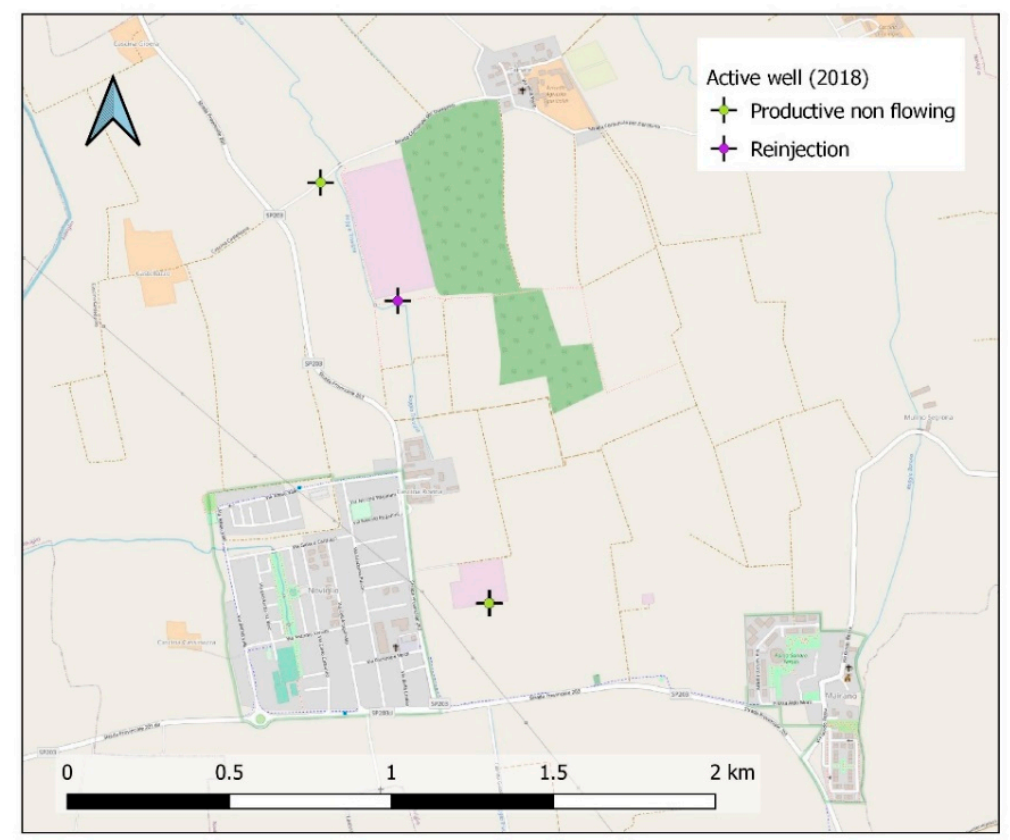

Figure 5. The Gaggiano field. Wells and Municipalities.

For the $6000 \mathrm{~m}^{2}$ of greenhouses in Gaggiano, the total installation cost is $0.33 \mathrm{M€}$. Considering as reference cultivation tomatoes, the selling price was assumed equal to $1.0 € / \mathrm{kg}$. The annual revenue of $0.09 \mathrm{M} €$ guarantees that in 3.67 years, the investment may be recovered.

Using the same evaluation procedure and the same species previously described for Galliate and Romentino aquaculture plant, the Gaggiano aquaculture plant presents a payback time of 5.1 years. Table 4 illustrates the basic data of plants and economic pre-feasibility.

Table 4. Gaggiano power plant.

\begin{tabular}{cccc}
\hline & DH Plant & Greenhouse Plant & Aquaculture Plant \\
\hline Inhabitants/Pond area & 4584 & $6000 \mathrm{~m}^{2}$ & $3200 \mathrm{~m}^{2}$ \\
Power (MW) & 3.92 & - & - \\
Supplied consumers & 1960 & - & - \\
Plant cost (M€) & 7 & 0.33 & 0.515 \\
Revenues per year (M€) & 0.95 & 0.09 & 0.10 \\
Payback time (year) & 7.4 & 3.7 & 5.1 \\
\hline
\end{tabular}

\subsection{Irminio}

The Irminio oil field (Figure 6) is located near the Irminio River between the municipalities of Ragusa and Scicli. The Irminio field belongs to the Late Triassic-Early Jurassic petroleum system in the Hyblean foreland domain in Sicily. There are currently four production wells and an oil centre, where oil is separated from natural gas and water and stored before marketing.

An evaluation of possible use in a greener way of the wells was studied. As a result, the oil company installed a cogeneration unit (CHP) with thermal power of $570 \mathrm{~kW}$ and electrical production of $360 \mathrm{~kW}$. The proposed solution was to design a roadmap for the conversion of the plant into a green plant, based on the use of produced heat both from wells and CHPs, to produce biogas and biomass for biodiesel production.

The flow rate produced by wells at a temperature of $40^{\circ} \mathrm{C}$ is sent to a heat exchanger to heat the anaerobic digester. To satisfy the thermal power demand of the digester, a part of the produced heat from the CHP is also supplied. The process temperature is around $35{ }^{\circ} \mathrm{C}$, working with mesophilic bacteria. The digester was designed based on the population in Scicli (262,000 people) and assumed to have an organic waste production of $130 \mathrm{~kg}$ per capita. The residence time chosen was 30 days for 
the digester and 60 days for the storage tank to obtain good digestion of the biomass. The daily production is $4038 \mathrm{~m}^{3}$ of biogas. The biogas can feed the CHP unit.

The larger part of the produced hot water from the CHP is used to produce algae. The algae farm is built close to a power plant, the $\mathrm{CO}_{2}$ produced by the power plant could be utilized as a carbon source for algal growth, and the carbon emissions would be reduced by recycling waste $\mathrm{CO}_{2}$ from power plants into clean-burning biodiesel. Practically, all the $\mathrm{CO}_{2}$ produced by the cogenerator will be introduced in the indoor pond to feed the algae. In this way, it is possible to feed $1800 \mathrm{~m}^{2}$ of ponds for algae cultivation.

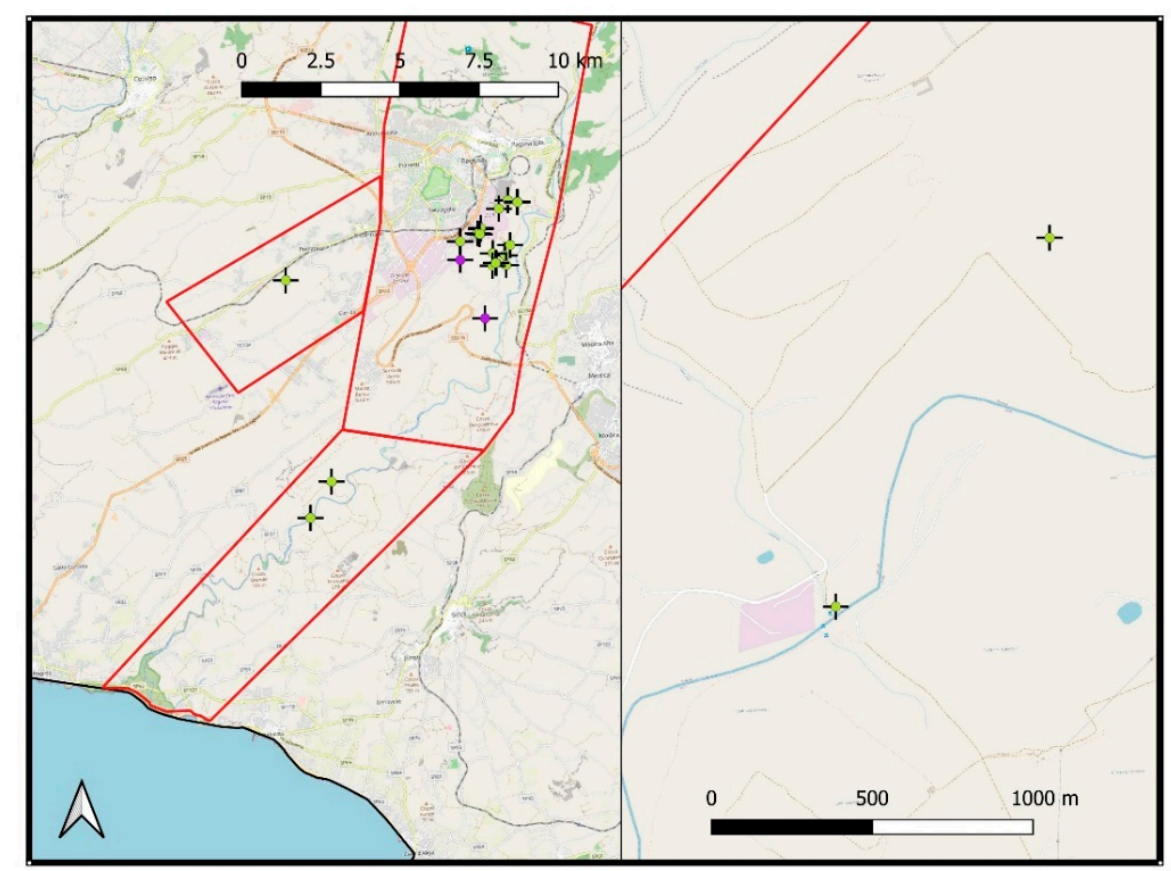

Figure 6. The Irminio field. Wells and Municipalities.

The biogas power plant (Table 5) has a total installation cost of $2.05 \mathrm{M} €$. Considering the price of electricity equal to $0.06 € / \mathrm{kWh}$, the annual revenue from electricity is $151,200 €$. Taking into account that almost $1000 \mathrm{~m}^{3}$ of biogas per day are consumed to supply the CHP, the remaining $1.1 \mathrm{Mm}^{3}$ of biogas can be sold each year, generating an annual income equal to $0.24 \mathrm{M} €$. The total annual revenue will be around $0.4 \mathrm{M} €$ and a simple payback period of 5.2 years is obtained.

Table 5. Irminio Biogas plant.

\begin{tabular}{cc}
\hline Installation cost & $2.05 \mathrm{M} €$ \\
Installed electrical power & $360 \mathrm{~kW}$ \\
Installed thermal power & $568 \mathrm{~kW}$ \\
Revenue from electricity & $151.200 € / \mathrm{y}$ \\
Gas produced & $1,108,761 \mathrm{~m}^{3}$ \\
Revenue from gas & $243,927 €$ \\
Annual revenue & $395,127 €$ \\
Payback time & 5.2 years \\
\hline
\end{tabular}

In Gela, on the refinery site is going to build a plant to distillate algae and produce biodiesel. This opportunity can be assumed to reduce the investment cost to build only the cultivation part to $170 € / \mathrm{m}^{2}$. The total installation cost (Table 6) concerning the $1800 \mathrm{~m}^{2}$ of indoor ponds is $306,000 €$. The annually produced biodiesel is $155,000 \mathrm{~L}$ and, considering a price of biodiesel equal to $0.452 € / \mathrm{L}$, the annual income is $70,000 €$. A simple payback period of 4.37 years is found. Of course, the cost for transporting algae must be taken into account for a more detailed analysis. 
Table 6. Irminio Biodiesel plant.

\begin{tabular}{ll}
\hline Area of the indoor pond & $1800 \mathrm{~m}^{2}$ \\
Installation plant cost & $306,000 €$ \\
Biodiesel produced & $155,000 \mathrm{~L} / \mathrm{y}$ \\
Annual revenue from biodiesel & $70,060 €$ \\
Payback time & 4.3 years \\
\hline
\end{tabular}

\section{Discussion and Conclusions}

The adopted selection method identified 42 fields: 23 fields deeper than $3000 \mathrm{~m}$ with an expected temperature higher than $70{ }^{\circ} \mathrm{C} ; 9$ fields with a depth between 2000 and $3000 \mathrm{~m}$ and a temperature higher than $70^{\circ} \mathrm{C}$; and 10 fields deeper than $2000 \mathrm{~m}$ with a temperature higher than $60^{\circ} \mathrm{C}$. However, it should be noted that due to the adopted simplified approach, the estimated number of fields may be slightly different where the actual temperature measurements are taken into consideration. One of the main issues in developing a systematic and detailed analysis was the lack of data, which are often covered by industrial secrets.

Three case studies were investigated in detail to identify a second life for the hydrocarbon wells: Villafortuna-Trecate, Gaggiano, and Irminio having in total 18 wells, 13 of which were production wells and the remaining 5 of which were injection wells. Below are listed the achievable results of the proposed reuse solutions:

- the generation of $9 \mathrm{MW}$ of electrical power.

- heating supply for 18,862 people thanks to $\mathrm{DH}$.

- $\quad$ heating supply of $10,500 \mathrm{~m}^{2}$ of enclosed ponds.

- $\quad$ heating supply for $6000 \mathrm{~m}^{2}$ of greenhouses.

- the disposal of 47,160 tons of organic waste to produce $4037.7 \mathrm{~m}^{3}$ /day of biogas.

- the cultivation of algae for the production of 150,000 L/year biodiesel in $1800 \mathrm{~m}^{2}$ of indoor ponds.

These results confirm the relevant benefits resulting from the repurposing of existing hydrocarbon wells for geothermal applications. It is necessary to emphasize that all these results are achieved without any emission of $\mathrm{CO}_{2}$ into the atmosphere. The same results also highlight the advantages for the local communities to produce a renewable energy source from the existing infrastructures, and the possibility for the companies to reduce abandonment costs. This last point can be a driving force to make available the basic data required to carry out a more detailed analysis of the Italian countryside.

Indeed, considering that in Italy 898 onshore wells with a productive or potentially productive operational status are present, a national project to assess the potential repurposing of oil and gas wells may be a great opportunity for the energy transition to renewables and the recovery of waste heat.

Conflicts of Interest: The authors declare no conflict of interest.

\section{References}

1. McKenna, J.; Blackwell, D.; Moyes, C.; Patterson, P.D. Geothermal electric power supply possible from Gulf Coast, Midcontinent Oil Field Waters. Oil Gas J. 2005, 103, 34-40.

2. Bennett, K.; Li, K.; Horne, R. Power generation potential from coproduced fluids in the Los Angeles Basin. In Proceedings of the Thirty-Seventh Workshop on Geothermal Reservoir Engineering, Stanford University, Stanford, CA, USA, 30 January-1 February 2012.

3. Wang, S.; Yan, J.; Li, F.; Hu, J.; Li, K. Exploitation and Utilization of Oilfield Geothermal Resources in China. Energies 2016, 9, 798, doi:10.3390/en9100798.

4. Wang, K.; Yuan, B.; Jia, G.; Wu, X. A comprehensive review of geothermal energy extraction and utilization in oilfields. J. Petroleum Sci. Eng. 2018, 168, 465-477.

5. Riney, T.D. Pleasant Bayou Geopressurised Geothermal Reservoir Analysis. J. Energy Resour. Technol. 1992, 114, 315-322. 
6. Barbacki, A.P. The use of abandoned oil and gas wells in Poland for recovering geothermal heat. In Proceedings of the World Geothermal Congress, Kyushu-Tohoku, Japan, 28 May-10 June 2000; pp. 1-5.

7. Zhang, L.; Yuan, J.; Liang, H.; Li, K. Energy from Abandoned Oil and Gas Reservoirs. In Proceedings of the Asia Pacific Oil and Gas Conference and Exhibition, Perth, Australia, 20-22 October 2008.

8. Johnson, L.; Walker, E. Ormat: Low-Temperature Geothermal Power Generation; The United States Department of Energy: Wyoming, WI, USA, 2010.

9. Nordquist, J.; Johnson, L. Production of Power from the Co-Produced Water of Oil Wells, 3.5 Years of Operation. In Proceedings of the Geothermal Resources Council Transactions, Geothermal Resources Council, Reno, NY, USA, 30 September-3 October 2012; Volume 36.

10. Limpasurat, A.; Falcone, G.; Teodoriu, C.; Barrufet, A. Unconventional heavy oil exploitation for waste energy recovery. In Proceedings of the SPE Latin American and Caribbean Petroleum Engineer Conference, Lima, Peru, 1-3 December 2010.

11. Sanyal, S.; Bulter, S. Geothermal power capacity for petroleum wells-Some case histories of assessment. In Proceedings of the World Geothermal Congress, Bali, Indonesia, 25-29 April 2010.

12. Li, T.; Zhu, J.; Zhang, W. Cascade utilization of low temperature geothermal water in oilfield combined power generation, gathering heat tracing and oil recovery. Appl. Thermal Eng. 2012, 40, 27-35.

13. Xin, S.; Liang, H.; Hu, B.; Li, K. Electrical power generation from low temperature co-produced geothermal resources at Huabei Oilfield. In Proceedings of the 37th Workshop on Geothermal Reservoir Engineering, Stanford, CA, USA, 30 January-1 February 2012.

14. Alimonti, C.; Gnoni, A. Harnessing the fluids heat to improve mature oil field: The Villafortuna-Trecate case study. J. Petroleum Sci. Eng. 2015, 125, 256-262.

15. Hu, K.; Zhu, J.; Zhang, W.; Li, X. A case study of an ORC geothermal power demonstration system under partial load conditions in Huabei Oilfield, China. Energy Procedia 2017, 142, 1327-1332.

16. Yang, Y.; Huo, Y.; Xia, W.; Wang, X.; Zhao, P.; Dai, Y. Construction and preliminary test of a geothermal ORC system using geothermal resource from abandoned oil wells in the Huabei oilfield of China. Energy 2017, 140, 633-645.

17. Gosnold, W. Electric Power Generation from Low to Intermediate Temperature Resources Executive; Technical Report; Univ. of North Dakota: Grand Forks, ND, USA, 2017.

18. Watson, S.M.; Falcone, G.; Westaway, R. Repurposing Hydrocarbon Wells for Geothermal Use in the UK: The Onshore Fields with the Greatest Potential. Energies 2020, 13, 3541.

19. Auld, A.; Hogg, S.; Berson, A.; Gluyas, J. Power production via North Sea Hot Brines. Energy 2014, 78, 674684.

20. Westaway, R. Repurposing of disused shale gas wells for subsurface heat storage: Preliminary analysis concerning UK issues. Q. J. Eng. Geol. Hydrogeol. 2016, 49, 213-227.

21. Liu, X.; Falcone, G.; Alimonti, C.A. systematic study of harnessing low-temperature geothermal energy from oil and gas reservoirs. Energy 2018, 142, 346-355.

22. Hirst, C.M.; Gluyas, J.G.; Mathias, S.A. The late field life of the East Midlands Petroleum Province: A new geothermal prospect? Q. J. Eng. Geol. Hydrogeol. 2015, 48, 104-114.

23. van der Molen, J.; Peters, E.; Jedari-Eyvazi, F.; van Gessel, S.F. Dual hydrocarbon-geothermal energy exploitation: Potential synergy between the production of natural gas and warm water from the subsurface. Neth. J. Geosci. 2020, 98, e12.

24. Falcone, G.; Liu, X.; Okech, R.R.; Seyidov, F.; Teodoriu, C. Assessment of deep geothermal energy exploitation methods: The need for novel single-well solutions. Energy 2018, 160, 54-63.

25. Westaway, R. Deep Geothermal SingleWell heat production: Critical appraisal under UK conditions. Q. J. Eng. Geol. Hydrogeol. 2018, 51, 424-449.

26. Trumpy, E.; Manzella, A. Geothopica and the interactive analysis and visualization of the updated Italian National Geothermal Database. Int. J. Appl. Earth Obs. Geoinf. 2017, 54, $28-37$.

27. Pieri, M.; Mattavelli, L. Geologic framework of Italian petroleum resources. AAPG Bull. 1986, 70, $103-130$.

28. Mattavelli, L.; Novelli, L. Geochemistry and habitat of oils in Italy. Am. Assoc. Petroleum Geol. Bull. 1990, 74, 1623-1639.

29. Mattavelli, L.; Novelli, L.; Anelli, L. Occurrence of hydrocarbons in the Adriatic Basin. Eur. Assoc. Petroleum Geosci. 1991, 1, 369-380.

30. Mattavelli, L.; Pieri, M.; Groppi, G. Petroleum exploration in Italy-A review. Marine Petroleum Geol. 1993, $10,410-425$. 
31. Anelli, L.; Mattavelli, L.; Pieri, M. Structural-stratigraphic evolution of Italy and its petroleum systems. Mèm. Mus. Natl. Hist. Nat. 1996, 170, 455-483.

32. Pieri, M. Italian petroleum geology. In Anatomy of an Orogen: The Apennines and Adjacent Mediterranean Basins; Vai, G.B., Martini, I.P., Eds.; Springer: Amsterdam, The Netherlands, 2001; pp. 533-550.

33. Casero, P. Structural setting of petroleum exploration plays in Italy. In Geology of Italy: Special Volume of the Italian Geological Society for the IGC 32 Florence-2004; Società Geologica Italiana: Rome, Italy, 2004; pp. 189199.

34. Bertello, F.; Fantoni, R.; Franciosi, R.; Gatti, V.; Ghielmi, M.; Pugliese, A. From thrust-and-fold belt to foreland: Hydrocarbon occurrences in Italy. In Petroleum Geology: From Mature Basins to New Frontiers, Proceedings of the 7th Petroleum Geology Conference; Geological Society of London: London, UK, 2010; pp. 113-126, doi:10.1144/0070113.

35. Cazzini, F.; Zotto, O.D.; Fantoni, R.; Ghielmi, M.; Ronchi, P.; Scotti, P. Oil and gas in the Adriatic foreland, Italy. J. Petroleum Geol. 2015, 38, 255-279.

36. Zappaterra, E. Source-rock distribution model of the Periadriatic Region. AAPG Bull. 1994, 78, 333-354.

37. Ziegler, P.A.; Roure, F. Petroleum systems of Alpine-Mediterranean fold belts and basins. In The Mediterranean Basins: Tertiary Extension within the Alpine Orogen; Durand, B., Jolivet, L., Horvnth, E., Sèranne, M., Eds.; Geological Society: London, UK, 1999; pp. 517-540.

38. Jenkyns, H.C. Geochemistry of oceanic anoxic events. Geochem. Geophys. Geosyst. 2010, 11, Q03004, doi:10.1029/2009GC002788.

39. Magoon, L.B.; Dow, W.G. The petroleum system. In The Petroleum System-From Source to Trap; AAPG: Tulsa, OK, USA, 1994; pp. 3-24.

40. UNMIG-MISE. National Mining Office for Hydrocarbon and Georesources of the Ministry for Economic Development. 2019. Available online: https://unmig.mise.gov.it/index.php/it/dati/ricerca-e-coltivazionedi-idrocarburi (accessed on 26 February 2020).

41. ViDEPI Project. Visibility of Petroleum Exploration Data in Italy. Ministry for Economic Development DGRME-Italian Geological Society-Assomineraria. 2019. Available online: http://www.videpi.com/videpi/videpi.asp (accessed on 26 February 2020).

42. Schlumberger. Well Evaluation Conference; WEC: Milan, Italy, 1987.

43. Sella, M.; Turci, C.; Riva, A. Sintesi geopetrolifera della Fossa Bradanica (avanfossa della catena appenninica meridionale). Mem. Soc. Geol. Ital. 1988, 41, 87-107.

44. HIS Energy Group. Italy, E\&P current licensing status. Map scale 1:1.250.000. In Proceedings of the 64th EAGE Conference, Florence, Italy, 27-30 May 2002.

45. Cataldi, R.; Mongelli, F.; Squarci, P.; Taffi, L.; Zito, G.; Calore, C. Geothermal ranking of Italian territory. Geothermics 1995, 1, 115-129.

Publisher's Note: MDPI stays neutral with regard to jurisdictional claims in published maps and institutional affiliations.

(C) 2020 by the authors. Licensee MDPI, Basel, Switzerland. This article is an open access article distributed under the terms and conditions of the Creative Commons Attribution (CC BY) license (http://creativecommons.org/licenses/by/4.0/). 